\title{
The soluble guanylyl cyclase activator BAY 60-2770 ameliorates detrusor dysfunction in obese mice
}

Gilberto de Nucci ${ }^{1,2^{*}}$, Luiz Osorio Leiria ${ }^{1}$, Fábio Henrique da Silva ${ }^{1}$, Eduardo C Alexandre ${ }^{1}$, Marina Calixto ${ }^{1}$, Fabíola Zakia Mónica', Edson Antunes ${ }^{1}$

From 6th International Conference on cGMP: Generators, Effectors and Therapeutic Implications

Erfurt, Germany. 28-30 June 2013

\section{Background}

The obesity-associated insulin resistance has been shown to play an important role in the pathophysiology of overactive bladder in mice $[1,2]$. Therefore, we evaluated the beneficial effects of long-term administration of the sGC activator BAY 60-2270 in bladders from lean and obese mice.

\section{Methods}

Mice were fed for 12 weeks with either a standard chow diet (carbohydrate: $70 \%$; protein: $20 \%$; fat: $10 \%$ ) or a high fat diet that induces obesity (carbohydrate: $29 \%$; protein: 16\%; fat: $55 \%$ ). Lean and obese mice were orally treated with BAY $60-2770(1 \mathrm{mg} / \mathrm{kg} /$ day, given as daily gavage

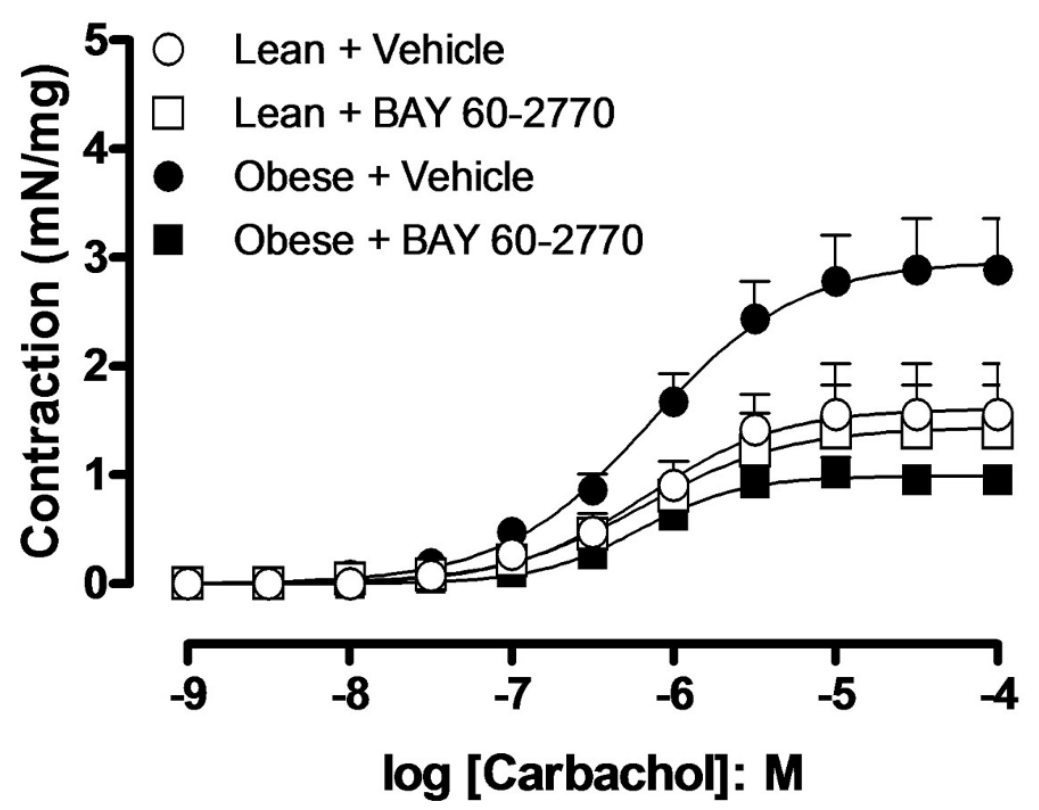

Figure 1 Concentration response curve to cabachol (0.001-100 $\mu \mathrm{M})$ in isolated bladder from lean and obese mice that received or not BAY 602770 (1 mg/Kg, 2 weeks). Data represent mean \pm S.E.M.

\footnotetext{
* Correspondence: denucci@gilbertodenucci.com

'Department of Pharmacology, State University of Campinas (UNICAMP), Brazil

Full list of author information is available at the end of the article
} 


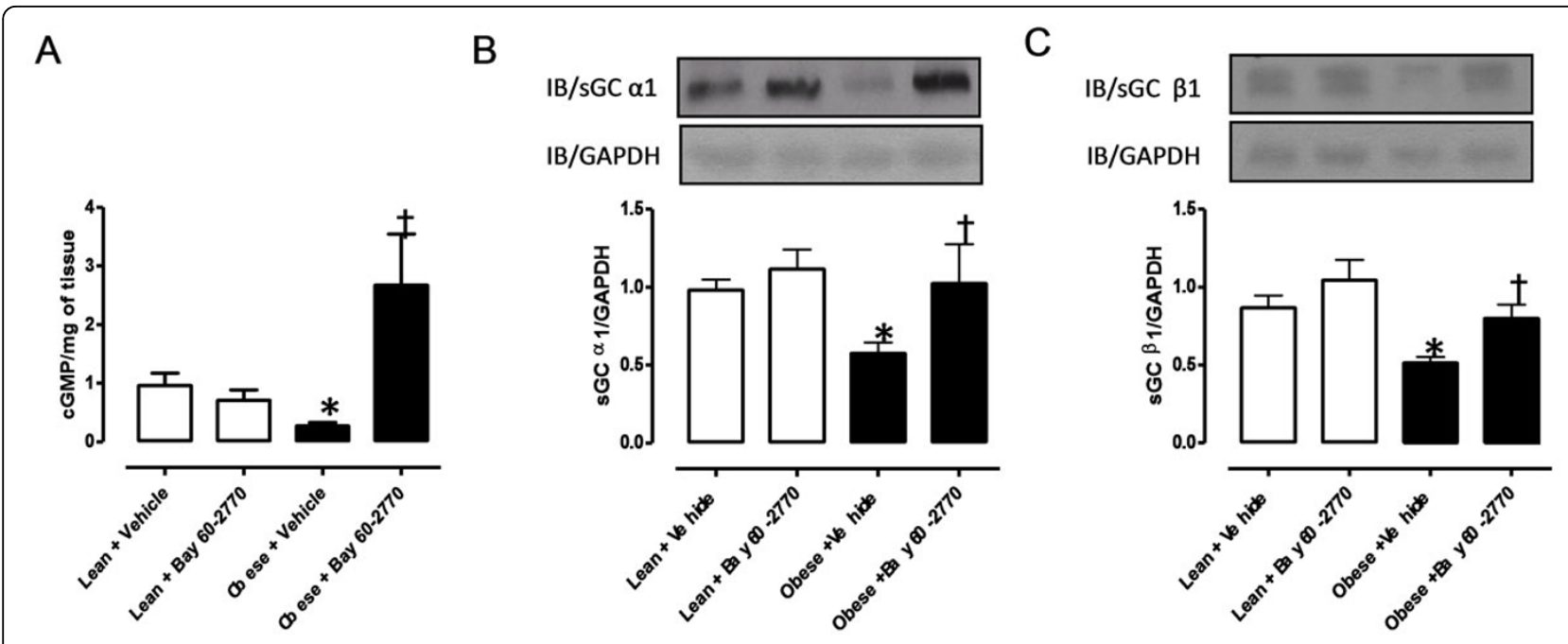

Figure 2 Effect of chronic treatment with BAY 60-2770 (1 mg/kg, 2 weeks) on cGMP levels (A) and protein expression of $\alpha_{1}$ (B) and $\beta_{1}$ (C) subunits of sGC in bladders from lean + vehicle, lean + BAY 60-2770, obese + vehicle and obese + BAY 60-2770 groups. Data are presented as mean \pm SEM. $\star p<0.05$ in comparison with lean + vehicle group; $+p<0.05$ in comparison to obese + vehicle group.

from the $10^{\text {th }}$ to the $12^{\text {th }}$ week) or its vehicle (Transcutol ${ }^{\mathbb{R}}$ : Cremophor ${ }^{\mathbb{B}}$ : water, 1:2:7, v/v/v). Concentration-response curves to full agonist carbachol $(\mathrm{CCh}, 0.001-100 \mu \mathrm{M})$ were obtained. The values of potency $\left(\mathrm{pEC}_{50}\right)$ and maximal responses $\left(E_{\max }\right)$ were calculated. The cGMP levels and Western blotting for $\alpha_{1}$ and $\beta_{1}$-subunit of sGC in the bladder tissues were also determined.

\section{Results}

Contractile response to the muscarinic agonist carbachol was greater $(\mathrm{p}<0.05, \mathrm{n}=5)$ in bladder from the obese in comparison with lean group. Long-term treatment with BAY 60-2770 normalized the enhanced contractile responses of the obese group, driving it to control levels $(\mathrm{p}<0.05$; figure 1). The cGMP levels in the bladder tissues from obese group were significantly lower in comparison with lean mice $(0.27 \pm 0.04$ and $0.95 \pm 0.14 \mathrm{pmol} / \mathrm{mg}$ tissue, respectively, $\mathrm{p}<0.05, \mathrm{n}=5$ ). Treatment with BAY 60 2770 generated a 10 -fold increase $(\mathrm{p}<0.01)$ in the bladder cGMP levels of obese mice, without affecting the levels in the lean group (Figure 2A). Protein expression of $\alpha_{1}$ and $\beta_{1}$ subunits of sGC was decreased by $41 \%$ and $43 \%$ $(\mathrm{p}<0.05)$ in bladder tissues of obese animals, respectively. However, oral treatment with BAY 60-2770 restored the protein levels of $\alpha_{1}$ and $\beta_{1}$ subunits to that of lean group (Figure 2B and 2C).

\section{Conclusion}

Chronic treatment with BAY 60-2770 results in amelioration of bladder dysfunction in high-fat obese mice.

\section{Authors' details}

${ }^{1}$ Department of Pharmacology, State University of Campinas (UNICAMP), Brazil. ${ }^{2}$ Institute of Biomedical Sciences, University of Sao Paulo (USP), Brazil.

\section{Published: 29 August 2013}

\section{References}

1. Leiria LO, Sollon C, Calixto MC, Lintomen L, Mónica FZ, Anhê GF, De Nucci G, Zanesco A, Grant AD, Antunes E: Role of PKC and CaV1.2 in detrusor overactivity in a model of obesity associated with insulin resistance in mice. PLOS One 2012, 7:e48507.

2. Leiria LO, Sollon C, Báu FR, Mónica FZ, D Ancona CL, De Nucci G, Grant AD Anhê GF, Antunes E: Insulin relaxes human and mice bladder via PI3K/ AKT/eNOS pathway activation in mucosal cells: UPR-dependent insulin resistance as a cause of obesity-associated overactive bladder. J Physiol 2013, 591:2259-2273.

doi:10.1186/2050-6511-14-S1-P18

Cite this article as: de Nucci et al:: The soluble guanylyl cyclase activator BAY 60-2770 ameliorates detrusor dysfunction in obese mice. BMC Pharmacology and Toxicology 2013 14(Suppl 1):P18.

\section{Submit your next manuscript to BioMed Central} and take full advantage of:

- Convenient online submission

- Thorough peer review

- No space constraints or color figure charges

- Immediate publication on acceptance

- Inclusion in PubMed, CAS, Scopus and Google Scholar

- Research which is freely available for redistribution 